\title{
Effects of 3-butenyl isothiocyanate on phenotypically different prostate cancer cells
}

\author{
M.J. NÚÑEZ-IGLESIAS ${ }^{1}$, S. NOVIO ${ }^{1}$, C. GARCÍA-SANTIAGO ${ }^{1}$, M.E. CARTEA ${ }^{2}$, \\ P. SOENGAS ${ }^{2}$, P. VELASCO ${ }^{2}$ and M. FREIRE-GARABAL ${ }^{1}$ \\ ${ }^{1}$ Screening of New Libraries Laboratory, School of Medicine and Dentistry, University of Santiago de Compostela, \\ 15782 A Coruña; ${ }^{2}$ Group of Genetics, Breeding and Biochemistry of Brassicas, \\ Biological Mission of Galicia, CSIC, 36143 Pontevedra, Spain
}

Received February 13, 2018; Accepted June 27, 2018

DOI: $10.3892 /$ ijo.2018.4545

\begin{abstract}
Isothiocyanates (ITCs) have gained increasing attention since they have been attributed the merits for the potential beneficial effects of cruciferous vegetable dietary consumption on cancer. The aim of the present study was to determine the cytotoxic effects of 3-butenyl ITC (3-BI) on prostate cancer (PC) cells under in vitro conditions. Two androgen-insensitive human PC cell lines, PC-3 and DU145, were assayed. Cells were cultured in the presence of increasing concentrations of $3-\mathrm{BI}(5,10,30$ and $50 \mu \mathrm{M})$ in the absence or presence of the chemotherapeutic drug docetaxel (DOCE) ( 1 and $2 \mathrm{nM}$ ). The cytotoxic effects of these compounds were analyzed using the trypan blue exclusion assay at 24,48 and $72 \mathrm{~h}$. Apoptosis and migration assays were also performed. The results showed that 3-BI induced a dose-dependent cytotoxic effect on PC-3 cells at 24,48 and $72 \mathrm{~h}$. These effects were significantly higher than those found with DOCE at $72 \mathrm{~h}$ of culture. Moreover, 3-BI also potentiated the effects of DOCE in a dose-dependent manner. Additionally, 3-BI showed inhibition of the migration of PC-3 cells. Nevertheless, 3-BI was not effective in the DU145 PC cell line. These results show a promising role for the 3-BI compound as a co-adjuvant agent in DOCE-based therapy in certain types of PC.
\end{abstract}

\section{Introduction}

Prostate cancer (PC) is a major health problem causing high morbidity and mortality worldwide (1). PC is a heterogeneous cancer phenotypically and biologically, particularly with regard to its hormone sensitivity. In order to reproduce this context in vitro, DU145 and PC-3 androgen-insensitive PC

Correspondence to: Dr S. Novio, Screening of New Libraries Laboratory, School of Medicine and Dentistry, University of Santiago de Compostela, C/San Francisco, s/n, Santiago de Compostela, 15782, A Coruña, Spain

E-mail: silvia.novio@usc.es

Key words: prostate cancer, isothiocyanates, docetaxel, synergism, proliferation, invasion, chemoprevention cells (AIPC) may be used. These cells differ in terms of tumor suppressor proteins, cell adhesion molecules and aggressiveness $(2-5)$.

Although the synthesis of androgens and androgen receptors (AR) constitutes a therapeutic target (6), there is currently no definitive treatment for PC beyond surgery or radiotherapy in the early stages of the disease. When recurrence occurs, androgen ablation therapy (ADT) is a standard systemic therapy. Although the initial response to treatment is high, after $\sim 18$ months there is a state of resistance to androgens, termed castration-resistant PC (CRPC) (7), which is associated in up to $40 \%$ of cases with metastasis and heterogeneity in the intra patient intermetastasis therapeutic response. The expected survival rate for patients with $\mathrm{PC}$ is $\sim 18 \%$, but when recurrences appear it decreases to $5-10 \%$ (8). Treatment options for CRPC and metastatic CRPC (mCRPC) include docetaxel (DOCE)-based regimens (9) alone or in association with, for example, ADT (10-13) or anti-angiogenic (bevacizumab), anti-proliferative and anti-migratory (tyrosine kinase inhibitors) drugs $(14,15)$. DOCE has been extensively used and is likely to continue to be used in PC, improving tumor response rate, time to progression and overall survival time (7). Although DOCE is a first-line reference drug in CRPC, side effects (15) and DOCE resistance (16) limit its clinical efficacy. Additionally, the widespread use of novel drugs is limited by the high cost (17). Therefore, there is a requirement to develop novel therapeutic strategies to improve efficacy and reduce adverse effects.

Phytochemicals are a heterogeneous set of bioactive compounds that are found naturally in vegetables, fruits, grains and other plant products. The compounds are often responsible for certain unique plant characteristics, including smell and pigmentation, and a number are vital for the protection of the host against parasites, viruses and other externally damaging agents. Moreover, phytochemicals could be compounds of interest in cancer chemoprevention due to their lower toxic effects compared with conventional chemotherapeutic drugs, their action on molecular targets involved in carcinogenesis (18) or their resensitizing effects on antiandrogen-resistant cells (19). An inverse correlation between consumption of cruciferous vegetables and cancer risk has been observed in PC and breast, colon, lung and gastric 
cancer (20-22). This effect has been attributed to a group of plant compounds, the isothiocyanates (ITCs), which are present in substantial concentrations in all brassica vegetables. ITCs are formed by the hydrolysis of their precursor parent compounds, the glucosinolates. The glucosinolates are a large group of sulphur-containing compounds that are present in all Brassica crops; a $\beta$-D-thioglucose group, a sulphonated oxime moiety and a variable side-chain derived from methionine, tryptophan or phenylalanine forms their common structure. Upon damage to the plant tissues during consumption, the endogenous enzyme myrosinase (thioglucoside glycohydrolase EC 3:2:3:1) and other gut enzymes hydrolize the glucosinolates to release a range of breakdown products, including the biologically active ITCs (23) (Fig. 1). ITCs have inhibitory effects on the metabolic activation of carcinogenic dietary or tobacco components (24), along with the inhibition of mutagenesis (25) and anti-carcinogenic effects in vitro (26-30) and in vivo (31,32). In PC, ITCs modulate epigenetic changes, induce the arrest of the cell cycle, activate apoptosis pathways and increase chemotherapeutic agent sensitivity; leading to the inhibition of cell proliferation, progression and invasionmetastasis (33).

ITCs are compounds with the structure $\mathrm{R}-\mathrm{N}=\mathrm{C}=\mathrm{S}$, where $\mathrm{R}$ is an alkyl or aryl group. One such ITC is 3-Butenyl ITC (3-BI), found particularly in brassica crops from Brassica rapa species, including pak choi, Chinese cabbage, turnips, turnip greens and turnip tops (34), where it is present as the glucosinolate gluconapin (Fig. 2). 3-BI is known to have multiple effects, including anti-proliferative and anti-apoptotic effects, on colon $(26,35)$, prostate, bone, cervical, liver, breast and neuroblastoma tumor cells (30). To date, there are no data on the effects of combination therapy of 3-BI and DOCE in PC. In order to elucidate this interaction, the present study examined the in vitro anticancer effects of 3-BI, with and without DOCE, using primary cultures of healthy human prostate epithelial cells (PECs) and the AIPC PC-3 and DU145 cell lines. Comparing the effects of 3-BI with or without DOCE on normal versus cancer cell lines will provide insight into their role in the treatment of $\mathrm{PC}$.

\section{Materials and methods}

Cell culture. Tumorigenic cell lines, DU145 (HTB-81) and PC-3 (cat. no. CRL-1435), and primary PECs (PCS-440-010; used to determine non-toxic nature of 3-BI only) were obtained from the American Type Culture Collection (ATCC; Manassas, VA, USA) and cultured according to company protocols with F-12K Medium (cat. no. 30-2004) and a Prostate Epithelial Cell Growth kit (cat. no. PCS-440-040) (both from ATCC), supplemented with fetal bovine serum (FBS; cat. no. 10270; Life Technologies; Thermo Fisher Scientific, Inc., Waltham, MA, USA) and $100 \mathrm{U} / \mathrm{ml}$ penicillin and $100 \mathrm{mg} / \mathrm{ml} \mathrm{strep-}$ tomycin (Penicillin-Streptomycin Solution 30-2300; LGC Standards SL, Barcelona, Spain). Stock solutions of 3-BI (cat. no. I0443; TCI, Paris, France) and DOCE (cat. no. 01885) were prepared in dimethyl sulfoxide (DMSO; cat. no. D2650) (both from Sigma-Aldrich; Merck KGaA, Darmstadt, Germany) and diluted with complete medium (medium supplemented with FBS, penicillin and streptomycin). An equal volume of DMSO (final concentration $<0.05 \%$ ) was added to the controls.
Cell viability assay. The effect of 3-BI and/or DOCE treatments on cell viability was determined by trypan blue dye exclusion assay as described previously (36). Briefly, $5 \times 10^{3}$ cells in $1 \mathrm{ml}$ complete medium were plated in 6-well plates and allowed to attach overnight. The medium was replaced with fresh complete medium containing different concentrations of 3 -BI $(0,5,10,30$ and $50 \mu \mathrm{M})$ and/or DOCE $(0,1$ and $2 \mathrm{nM})$, and the plates were incubated for 24,48 or $72 \mathrm{~h}$ at $37^{\circ} \mathrm{C}$. At the end of the incubation period, floating and adherent cells were collected and suspended in $25 \mathrm{ml}$ phosphate-buffered saline (PBS; cat. no. D8537; Sigma-Aldrich; Merck KGaA). The cells were then mixed with $5 \mathrm{ml} \mathrm{0.4 \%}$ trypan blue solution (cat. no. T6146; Sigma-Aldrich; Merck KGaA), and live and dead cells were counted under an Olympus inverted microscope (Olympus, Tokyo, Japan).

Determination of apoptosis. Apoptosis induction by 3-BI and/or DOCE treatments, at the same concentrations that were used to evaluate cellular viability, was assessed by fluorescence microscopy following staining with 4',6-diamidino-2-phenylindole (DAPI), caspase-3 activation assay and cleaved poly(ADP-ribose) polymerase (PARP) assay.

Fluorescence microscopy. Cells $\left(2 \times 10^{4}\right)$ were plated on coverslips, allowed to attach overnight, and exposed to DMSO or 3-BI and/or DOCE at the same concentrations that were used to evaluate cellular viability, for $72 \mathrm{~h}$. The cells were washed with PBS and fixed with $3 \%$ paraformaldehyde for $1 \mathrm{~h}$ at room temperature. The cells were washed three times with PBS, permeabilized with $1 \%$ Triton X-100 (cat. no. 142314.1611142314.1611; Panreac Quimica SLU, Barcelona, Spain) for $4 \mathrm{~min}$, washed again with PBS and stained with $1 \mu \mathrm{g} / \mathrm{ml}$ DAPI (cat. no. D9542; Sigma-Aldrich; Merck KGaA) for $5 \mathrm{~min}$. The cells with condensed and fragmented DNA (apoptotic cells) were counted under a fluorescence microscope at x40 magnification (37).

Caspase-3 activity and cleaved PARP assay. The effect of 3-BI and/or DOCE treatments on caspase-3 activity and cleaved PARP level in PC-3 cells was determined using commercially available ELISA kits. Active caspase- 3 and cleaved PARP levels (ng/mg total protein of cell lysate) were determined, and the results were expressed relative to the control. Briefly, $1 \times 10^{4}$ cells were plated in 24 -well plates and allowed to attach overnight. Next, the cells were treated with DMSO, $50 \mu \mathrm{M} 3-\mathrm{BI}, 2 \mathrm{nM}$ DOCE or $50 \mu \mathrm{M} 3-\mathrm{BI}+2 \mathrm{nM}$ DOCE for $72 \mathrm{~h}$ at $37^{\circ} \mathrm{C}$. The cells were collected and lysed in cell extraction buffer (cat. no. FNN0011; Thermo Fisher Scientific, Inc.) mixed with protease inhibitor cocktail (cat. no. P-2714) and $1 \mathrm{mM}$ phenyl methane sulfonyl fluoride (cat. no. 10837091001) (both from Sigma-Aldrich; Merck KGaA). ELISA assays for caspase-3 activity (cat. no. KHO1091) and cleaved PARP level (cat. no. 10650704) (both from Thermo Fisher Scientific, Inc.) were performed according to the manufacturer's protocols.

In vitro migration assay. The effect of $3-\mathrm{BI}(0,5,10,30$ and $50 \mu \mathrm{M})$ on PC-3 and DU145 cell migration was assessed using 24-well Transwell cell culture chambers $(6.5-\mathrm{mm}$ diameter, 8.0- $\mu \mathrm{m}$ pore size, polycarbonate membrane) (cat. no. C6932; Sigma-Aldrich; Merck KGaA) with a Millicell Cell Culture 


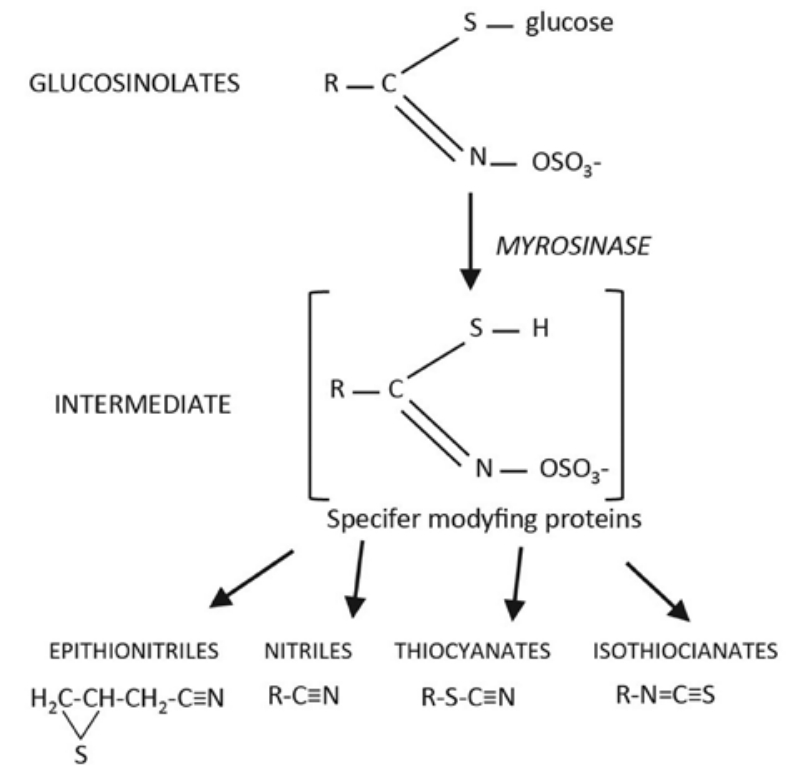

Figure 1. General structure of glucosinolates and their enzymatic degradation products.

Insert (cat. no. PI8P01250; Merck KGaA) (38). Briefly, 1x105 cells were added into the upper chamber with $100 \mu \mathrm{l}$ serum-free medium. The lower chamber was filled with $600 \mu \mathrm{l}$ complete medium containing $10 \%$ fetal bovine serum (Life Technologies; Thermo Fisher Scientific, Inc.). After $24 \mathrm{~h}$ of incubation at $37^{\circ} \mathrm{C}$ in a $5 \% \mathrm{CO}_{2}$ incubator, the cells in the upper chamber were carefully removed with a cotton swab and the cells that had migrated through the membrane and had stuck to the lower surface of the membrane were fixed with $4 \%$ paraformaldehyde (20 min at room temperature) and stained with crystal violet (cat. no. C6158; Sigma-Aldrich; Merck KGaA) (15 min at room temperature). For quantification, the stained cells were counted by capturing images of the membrane under a microscope in five randomly selected fields using an Olympus microscope with a digital camera (Olympus, Tokyo, Japan). At least three chambers from three different experiments were analyzed.

Confocal microscopy. As 3-BI exhibited noticeable effects on PC-3 cells but not in DU 145 cells (see Results section), PC-3 cells were seeded in glass coverslips into incubation chambers for $24 \mathrm{~h}$ at $37^{\circ} \mathrm{C}$ and with $5 \% \mathrm{CO}_{2}$ for full adherence. Next, the medium was replaced with fresh complete medium without adding any treatment (control) or containing 3-BI $50 \mu \mathrm{M}$ and/or DOCE (1 and $2 \mathrm{nM})$, and the cells were incubated for $72 \mathrm{~h}$ at $37^{\circ} \mathrm{C}$. Subsequently, the PC-3 cells were fluorescently stained for F-actin (Phalloidin-ATTO 647N; 1:500; cat. no. 65906; Sigma-Aldrich; Merck KGaA), nuclei (DAPI) and cytoplasm [Carboxyfluorescein diacetate succinimidyl ester (CFDA-SE); cat. no. 1351201EDU; Bio-Rad Laboratories, Inc., Hercules, CA, USA] according to the following procedure. The culture medium was replaced by PBS solution containing fluorescent dye CFDA-SE at $1 \mathrm{mM}$ and the cells were incubated for $15 \mathrm{~min}$ at room temperature. Following incubation, CFDA-SE solution was removed and the cells were washed with PBS, fixed with $70 \%$ ethanol for $5 \mathrm{~min}$, washed again with PBS and stained for with Phalloidin-ATTO for $1 \mathrm{~h}$ at room temperature. Next, the cells were washed with $0.9 \%$ sodium chloride (cat. no. S7653;

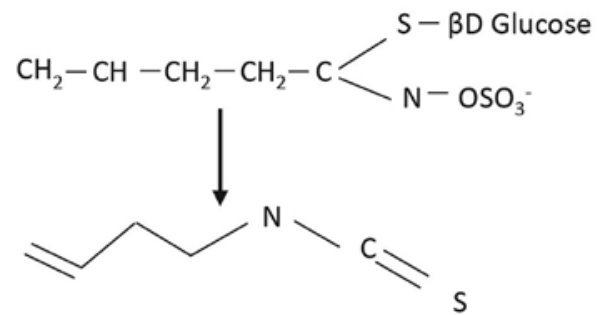

Figure 2. Structure of glucosinolate gluconapin and its enzymatic degradation product, 3-butenyl isothiocyanate.

Sigma-Aldrich; Merck KGaA) and stained with DAPI at $1 \mu \mathrm{g} / \mathrm{ml}$ for $10 \mathrm{~min}$ at room temperature. Thereafter, slides were embedded in Vecta Shield antifade mounting medium (cat. no. H-1000; Vector Laboratories, Inc., Burlingame, CA, USA). A Leica confocal microscope (Leica TCS SP5 X microscope; Leica Microsystems, Inc., Buffalo Grove, IL, USA) was used for the analysis of the cells (39).

Statistical analysis. The results represent the mean of at least three independent experiments (mean \pm standard deviation). The significance of difference in measured variables between control and treated groups was studied by two-way analysis of variance. Significance between multiple experimental groups was determined using Tukey's post hoc analysis. P $\leq 0.05$ was considered to indicate a statistically significant difference.

\section{Results}

Inhibition of $P C$ cell proliferation by 3-BI and/or DOCE. The effect of 3-BI treatment on the survival of PC-3 and DU145 cells was assessed by trypan blue dye exclusion assay (Fig. 3). The viability of the DU145 cells was not affected by 3-BI (Fig. 3B), whereas the compound significantly inhibited the survival of PC-3 cells in a concentration- and time-dependent manner (Fig. 3A). The inhibitory effect of 3-BI was most pronounced at doses of $50 \mu \mathrm{M}(30 \%$ at $24 \mathrm{~h})$. Otherwise, survival of PECs was minimally affected $(\mathrm{P}>0.05)$ by 3 -BI. Thus, $\sim 96 \%$ of PECs were viable following a 72-h exposure to $50 \mu \mathrm{M} 3$-BI (Table I), whereas only $\sim 30 \%$ of PC-3 survived under similar conditions to 3-BI treatment.

3-BI was more effective in PC-3 cells than DOCE only at $72 \mathrm{~h} ; 50 \mu \mathrm{M} 3$-BI reduced PC-3 cell viability by $\sim 70 \%$, whereas $2 \mathrm{nM}$ DOCE alone inhibited the growth of these cells by $\sim 35 \%$.

Sensitization of PC cells to growth suppression by DOCE. Growth inhibition of PC-3 cells (but not of DU145 cells) by DOCE was increased by 3-BI. Fig. 3 shows the viability of PC cells following 24-72 $\mathrm{h}$ of exposure to 3-BI and/or DOCE, as assessed by trypan blue dye exclusion assay.

The 3-BI and DOCE combination was significantly more efficacious against the viability of PC-3 cells compared with 3-BI or DOCE treatment alone. This effect was not observed for DU145 cells, so the 3-BI-mediated sensitization to growth suppression by DOCE was a cell line-specific response. Analyzing the results using a previously described method (40), it was observed that 3-BI synergistically enhanced the anti-proliferative effects of DOCE on PC-3 cells at 24 and $48 \mathrm{~h}$ when the lowest dose of the chemotherapy drug 
was administered (Table II). For example, the viability of the PC-3 cells was slightly affected in the presence of $1 \mathrm{nM}$ DOCE alone for $48 \mathrm{~h}$ (95\%), while exposure to $50 \mu \mathrm{M} 3-\mathrm{BI}$ resulted in a survival rate of $73 \%$ compared with that in the DMSO-treated control group. The viability of PC-3 cells was reduced by $\sim 53 \%$ by a 48 -h co-treatment with $50 \mu \mathrm{M} 3-\mathrm{BI}$ and $1 \mathrm{nM}$ DOCE in comparison with that of the vehicle-treated control cells, with an observed combination index of 1.47, indicating synergy between 3-BI and DOCE (Table II).

Apoptosis. Apoptotic induction by 3-BI was assessed by fluorescence microscopy subsequent to staining with DAPI (Fig. 4). Furthermore, taking into account that characteristic events of apoptosis include proteolytic activation of caspase-3, and proteolytic cleavage of PARP-1, PARP and caspase- 3 cleavage measurements were performed. It was concluded that the 3-BI-mediated death of androgenindependent PC cells induced by 3-BI cannot be explained by apoptotic mechanisms, as apoptotic cells were rarely observed in the cultures of PC-3 cells following a 72-h treatment with 3-BI (Fig. 5).

Migration. Transwell chamber assays were used to assess the effects of 3-BI on PC-3 and DU145 cell migration. In contrast to that in DU145 cells, following 3-BI treatment for $72 \mathrm{~h}$, the migration ability of the PC-3 cells was decreased, with its maximum effect at $50 \mu \mathrm{M}$ (Fig. 6).

Confocal microscopy. To investigate the role of 3-BI in cell damage in PC-3, cytopathic changes were examined (Fig. 7). As the maximum effect had previously been observed at $50 \mu \mathrm{M} 3-\mathrm{BI}$, this dose was used as the treatment concentration in this experiment. In the control group, PC-3 cells showed elongated morphology, cell appendages (arrows), ellipsoid nuclei with euchromatin and heterochromatin, actin filaments localized mainly beneath the plasma membrane and the cytoplasm stained homogenously with CFDA-SE. In the treatment groups (50 $\mu \mathrm{M} 3-\mathrm{BI}, 50 \mu \mathrm{M} 3-\mathrm{BI}$ and $1 \mathrm{nM}$ DOCE, and $50 \mu \mathrm{M}$ 3 -BI and $2 \mathrm{nM}$ DOCE) the cells exhibited a rounded shape as the predominant phenotype and actin skeleton reorganization with actin dislocation into the perinuclear zone.

\section{Discussion}

The present study found that the PC-3 cell line, but not the DU145 cell line, was sensitive to survival inhibition induced by 3 -BI. This was a time- and dose-dependent effect. At the highest doses and more prolonged times of exposure, PC-3 cell survival was $\sim 30 \%$. By contrast, survival of PECs was $~ 96 \%$. These findings may be noteworthy since the ability of a chemopreventive agent to cause specific cytotoxicity in cancer cells and not in normal cells is an important determinant of its clinical relevance and safety.

There are a few studies on the effects of 3-BI on cancer cells under in vitro conditions $(26,30,35)$. Other 3-butenyl ITCs, including 4-methylthio-3-BI-ITC (raphasatin) or 4-methylsulfinyl-3-BI-ITC (sulforaphene), have been found not to cause toxicity in $\mathrm{T}$ lymphocytes, despite being cytotoxic in Jurkat T-leukemia (41), colon cancer (LoVo, CaCo-2, HCT-116 and HT-29) $(42,43)$ and breast cancer (MDA-MB-231 and MCF-7) (43) cells.
Table I. Effects of the treatment with 3-BI (72 h) on proliferation of PEC cells, as determined by trypan blue dye exclusion assay.

\begin{tabular}{lrcc}
\hline & & \multicolumn{2}{c}{ Cell proliferation } \\
\cline { 3 - 4 } DOCE, nM & 3 -BI, $\mu \mathrm{M}$ & Mean $(\%)$ & $\mathrm{SD}$ \\
\hline 0 & 0 & 98.04 & 0.52 \\
0 & 5 & 97.55 & 1.37 \\
0 & 10 & 98.52 & 1.26 \\
0 & 30 & 96.52 & 0.57 \\
0 & 50 & 95.64 & 1.32 \\
1 & 0 & 93.43 & 0.97 \\
1 & 5 & 96.75 & 1.01 \\
1 & 10 & 96.40 & 1.34 \\
1 & 30 & 95.32 & 0.98 \\
1 & 50 & 95.35 & 1.19 \\
2 & 0 & 96.48 & 1.08 \\
2 & 5 & 96.37 & 1.33 \\
2 & 10 & 95.51 & 0.95 \\
2 & 30 & 96.48 & 0.77 \\
2 & 50 & 96.04 & 0.90 \\
\hline
\end{tabular}

Results are expressed relative to the control. No significant differences were found compared with the control treatment. 3-BI, 3-butenyl isothiocyanate; DOCE, docetaxel; SD, standard deviation.

Unlike other ITCs, the molecular mechanisms by which 3-BI produces an inhibitory effect on the survival and proliferation of cancer cells are not fully known. The anti-proliferative effect of ITCs is usually associated with cell cycle arrest and the activation of apoptosis $(33,44,45)$. Regarding cell cycle arrest, previous studies have found that sulforaphene inhibits proliferative activity by increasing the expression of p21 (cyclin-dependent kinase inhibitor), which in turn promotes G1 cell cycle phase arrest (esophageal carcinogenesis in vivo). By contrast, sulforaphene induces apoptosis through increased expression of p21 (32), downregulation of the B-cell lymphoma-2 (Bcl-2)/apoptosis regulator BAX (Bax) ratio (in vivo) and activation of caspase-3 and -9 (in vitro, A549 lung cancer cells) (46). In the present study, few apoptotic cells were observed following 3-BI treatment of PC-3 cells, suggesting that the effect of 3-BI could be mediated through other pathways, which will be investigated in future studies. These controversial results may be due to the different cell and ITC characteristics and/or ITC treatment concentrations.

In an attempt to overcome DOCE resistance, the effective cytotoxic, apoptotic and anti-migratory concentrations of the microtubule-targeting drug DOCE and 3-BI, and the synergistic effects in DU145 and PC-3 CRPC lines were studied. DU145 cells are p53-mutant, Bax-negative, signal transducer and activator of transcription 3 (STAT3)-positive and E-cadherin-positive, while PC-3 cells are p53-null, STAT3-negative, and phosphatase and tensin homologue (PTEN)-negative, with negative or low E-cadherin expression and high matrix metalloproteinase (MMP)1 and 3 expression; therefore making PC-3 cells more aggressive $(2-5,47)$. Furthermore, PC-3 cells show features that are characteristic of prostatic small cell neuroendocrine PC (48). 
Table II. Analysis of synergy between 3-BI and DOCE calculated by survival rate for PC-3 cells.

\begin{tabular}{|c|c|c|c|c|c|c|c|c|c|c|}
\hline \multirow[b]{2}{*}{ Time, $\mathrm{h}$} & \multicolumn{3}{|c|}{ DOCE } & \multicolumn{3}{|c|}{ 3-BI } & \multicolumn{3}{|c|}{ Combination treatment } & \multirow[b]{2}{*}{ Index $^{\mathrm{e}}$} \\
\hline & Dose, $\mathrm{nM}$ & $\mathrm{MSR}^{\mathrm{a}}$ & P-value ${ }^{b}$ & Dose, $\mathrm{nM}$ & MSR & P-value & Expected $^{c}$ & Observed $^{\mathrm{d}}$ & P-value & \\
\hline 24 & 1 & 0.99 & $>0.05$ & 5 & 0.97 & $>0.05$ & 0.96 & 0.58 & $<0.05$ & 1.66 \\
\hline 24 & 1 & 0.99 & $>0.05$ & 10 & 0.72 & $<0.05$ & 0.71 & 0.36 & $<0.05$ & 1.97 \\
\hline 24 & 1 & 0.99 & $>0.05$ & 30 & 0.69 & $<0.05$ & 0.68 & 0.36 & $<0.05$ & 1.89 \\
\hline 24 & 1 & 0.99 & $>0.05$ & 50 & 0.71 & $<0.05$ & 0.70 & 0.33 & $<0.05$ & 2.12 \\
\hline 24 & 2 & 0.37 & $<0.05$ & 5 & 0.97 & $>0.05$ & 0.36 & 0.48 & $<0.05$ & 0.75 \\
\hline 24 & 2 & 0.37 & $<0.05$ & 10 & 0.72 & $<0.05$ & 0.27 & 0.37 & $<0.05$ & 0.73 \\
\hline 24 & 2 & 0.37 & $<0.05$ & 30 & 0.69 & $<0.05$ & 0.26 & 0.36 & $<0.05$ & 0.72 \\
\hline 24 & 2 & 0.37 & $<0.05$ & 50 & 0.71 & $<0.05$ & 0.26 & 0.34 & $<0.05$ & 0.76 \\
\hline 48 & 1 & 0.95 & $>0.05$ & 5 & 0.75 & $<0.05$ & 0.71 & 0.55 & $<0.05$ & 1.29 \\
\hline 48 & 1 & 0.95 & $>0.05$ & 10 & 0.75 & $<0.05$ & 0.71 & 0.46 & $<0.05$ & 1.54 \\
\hline 48 & 1 & 0.95 & $>0.05$ & 30 & 0.76 & $<0.05$ & 0.72 & 0.47 & $<0.05$ & 1.53 \\
\hline 48 & 1 & 0.95 & $>0.05$ & 50 & 0.73 & $<0.05$ & 0.69 & 0.47 & $<0.05$ & 1.47 \\
\hline 48 & 2 & 0.38 & $<0.05$ & 5 & 0.75 & $<0.05$ & 0.29 & 0.55 & $<0.05$ & 0.53 \\
\hline 48 & 2 & 0.38 & $<0.05$ & 10 & 0.75 & $<0.05$ & 0.29 & 0.41 & $<0.05$ & 0.71 \\
\hline 48 & 2 & 0.38 & $<0.05$ & 30 & 0.76 & $<0.05$ & 0.29 & 0.39 & $<0.05$ & 0.74 \\
\hline 48 & 2 & 0.38 & $<0.05$ & 50 & 0.73 & $<0.05$ & 0.28 & 0.39 & $<0.05$ & 0.72 \\
\hline 72 & 1 & 0.95 & $>0.05$ & 5 & 0.56 & $<0.05$ & 0.53 & 0.54 & $>0.05$ & 0.98 \\
\hline 72 & 1 & 0.95 & $>0.05$ & 10 & 0.45 & $<0.05$ & 0.43 & 0.46 & $>0.05$ & 0.93 \\
\hline 72 & 1 & 0.95 & $>0.05$ & 30 & 0.32 & $<0.05$ & 0.30 & 0.48 & $>0.05$ & 0.63 \\
\hline 72 & 1 & 0.95 & $>0.05$ & 50 & 0.30 & $<0.05$ & 0.29 & 0.47 & $<0.05$ & 0.62 \\
\hline 72 & 2 & 0.33 & $<0.05$ & 5 & 0.56 & $<0.05$ & 0.18 & 0.46 & $<0.05$ & 0.39 \\
\hline 72 & 2 & 0.33 & $<0.05$ & 10 & 0.45 & $<0.05$ & 0.15 & 0.42 & $<0.05$ & 0.36 \\
\hline 72 & 2 & 0.33 & $<0.05$ & 30 & 0.32 & $<0.05$ & 0.11 & 0.30 & $<0.05$ & 0.37 \\
\hline 72 & 2 & 0.33 & $<0.05$ & 50 & 0.30 & $<0.05$ & 0.10 & 0.30 & $<0.05$ & 0.33 \\
\hline
\end{tabular}

3-BI, 3-butenyl isothiocyanate; DOCE, docetaxel; MSR, mean survival rate. ${ }^{\mathrm{a}} \mathrm{MSR}$ of treated group compared with dimethyl sulfoxide-treated

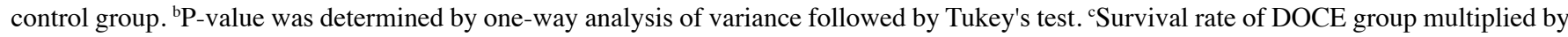
survival rate of the 3-BI group. ${ }^{\mathrm{d}}$ Survival rate of combination treatment group (DOCE $\left.+3-\mathrm{BI}\right)$. Index was calculated by dividing the expected survival rate by the observed survival rate. An index of $>1$ indicates a synergistic effect and an index of $<1$ indicates less than additive effect.

The present results demonstrated that 3-BI synergizes with DOCE against cultured human PC-3 AIPC cells. To the best of our knowledge, the present study is the first published report to document this synergistic anti-proliferative effect. This effect could be explained by interaction with a DOCE molecular mechanism (some of which are already under investigation by our group): i) DOCE is a well-known microtubule-target agent (49). Certain ITCs, including allyl-ITC (45), benzyl-ITC, phenethylITC and 4-methyl-sulphynilbutyl-ITC (SFN) (50-52), interact with microtubules causing inhibition of tubulin polymerization, tubulin depolymerization, histone deacetylase inhibition or tubulin acetylation (Fig. 8). ii) DOCE induces Bcl-2 phosphorylation, which in turn causes cellular apoptosis through different routes (53). Bcl-2 is associated with the development of AIPC, being overexpressed in advanced stages of the disease. Bcl-2 proteins, independent of their known anti-apoptotic effects, are also implicated in cancer cell migration and invasion. Certain ITCs can upregulate Bcl-2 (33). iii) DOCE inhibits androgendependent and -independent activation of AR. The association between AR and tubulin, and the preferential binding of microtubules to AR can recruit AR to determine apoptotic-signaling promotion and tumor growth inhibition (54). SFN can decrease the expression of $\mathrm{AR}$ in a dose- and time-dependent manner in PC cells (55). The chemical structure of this ITC determines this effect. Thus, while propyl-, butyl- and pentyl-thio analogues have similar effectiveness, sulfonyl derivatives of SFN are either inactive or less effective than the thio- or sulfinyl-derivatives (56).

On the other hand, the present study observed that 3-BI-mediated DOCE sensitization to growth suppression was significantly higher in the PC-3 cell line as opposed to that in the DU145 cell line. Although the precise mechanism underlying this divergence is not known, it could likely be attributed to differential cells characteristics, particularly with regard to p53, STAT3 and PTEN. The tumor suppressor p53 is expressed in response to different stresses (57), orchestrating biological outputs such as cell proliferation, apoptosis, cell-cycle arrest or autophagy (58). In advanced PC, a complete loss of p53 is found (59) and a lack or mutation of p53 is associated with chemotherapeutic resistance (60-62). As the PC-3 and DU145 cell lines lack functional p53, similarities could be expected; however, according to Muller and Vousden (63), mutant p53 
A

$24 \mathrm{~h}$

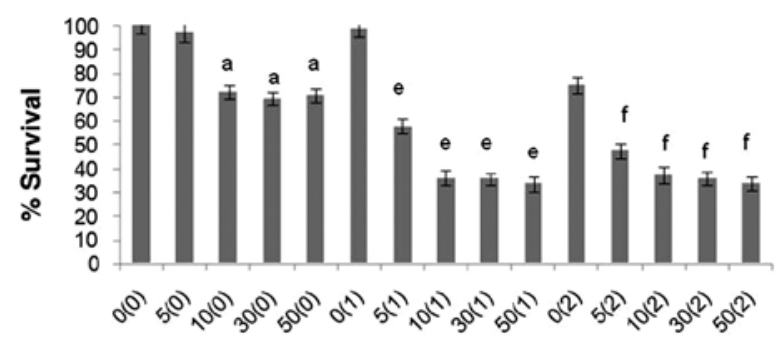

3-BI $\mu \mathrm{M}$ (DOCE nM)

$48 \mathrm{~h}$

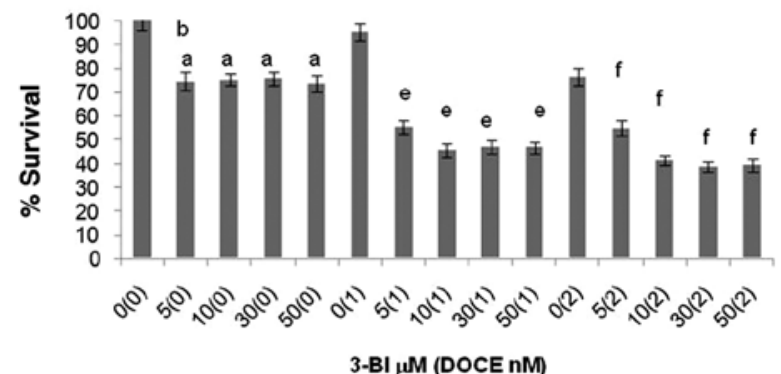

$72 \mathrm{~h}$

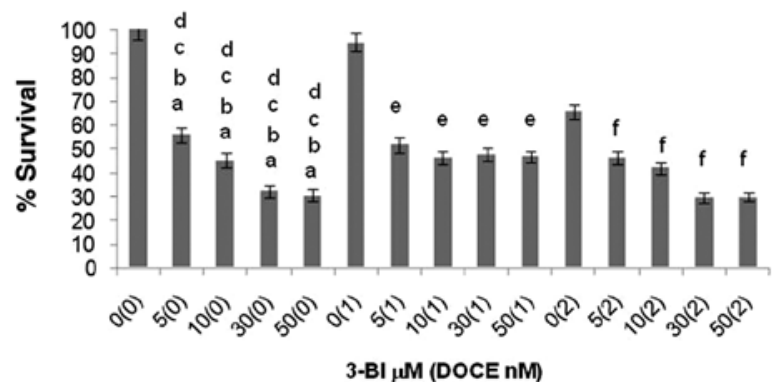

B

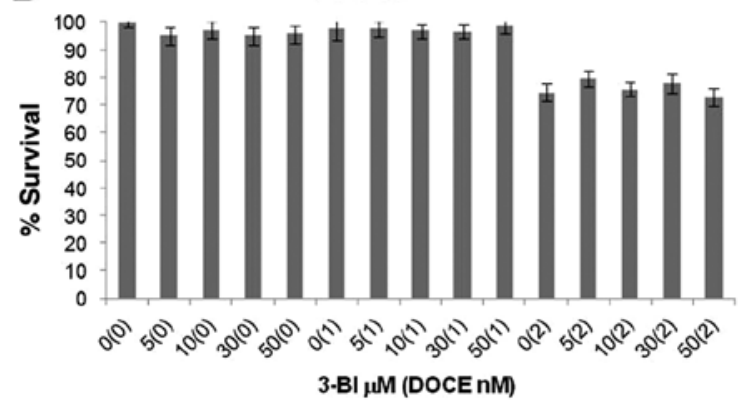

$48 \mathrm{~h}$

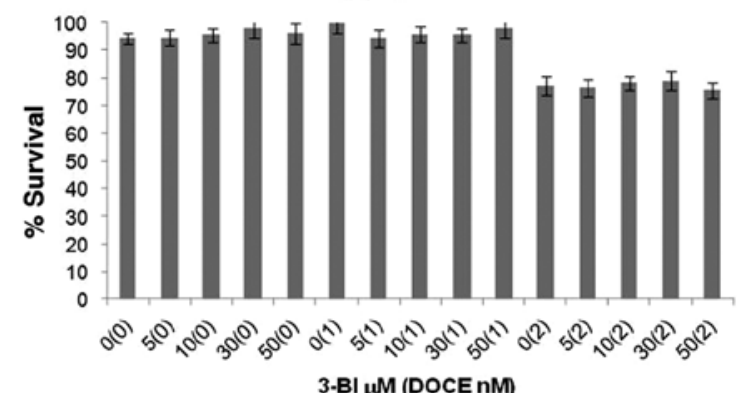

$72 \mathrm{~h}$

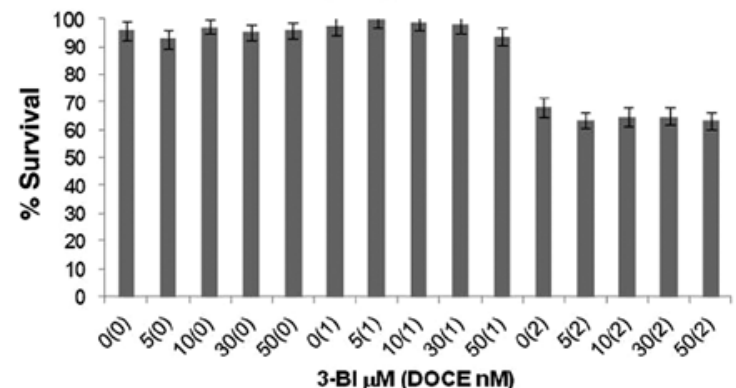

Figure 3. Time-course and dose-response of 3-BI treatment effects on proliferation of (A) PC-3 and (B) DU145 cells, as determined by trypan blue dye exclusion assay. Columns, mean; bars, standard deviation $(\mathrm{n}=3)$. ${ }^{\mathrm{a}} \mathrm{P}<0.05,3$ - $\mathrm{BI}$ treatment alone compared with control treatment; ${ }^{\mathrm{b}} \mathrm{P}<0.05,3-\mathrm{BI}$ treatment alone for 48 or $72 \mathrm{~h}$ compared with 3-BI treatment alone for $24 \mathrm{~h} ;{ }^{\circ} \mathrm{P}<0.05,3$-BI treatment alone for $72 \mathrm{~h}$ compared with 3-BI treatment alone for $48 \mathrm{~h}$; ${ }^{\mathrm{d}} 3$-BI treatment alone compared with $2 \mathrm{nM}$ DOCE alone; ${ }^{\mathrm{e}}$ combination treatment (3-BI $+1 \mathrm{nM}$ DOCE) compared with $1 \mathrm{nM}$ DOCE alone; ${ }^{\mathrm{f}}$ combination treatment (3-BI + $2 \mathrm{nM}$ DOCE) compared with $2 \mathrm{nM}$ DOCE alone (one-way analysis of variance and Tukey's post hoc). 3-BI, 3-butenyl isothiocyanate; DOCE, docetaxel.

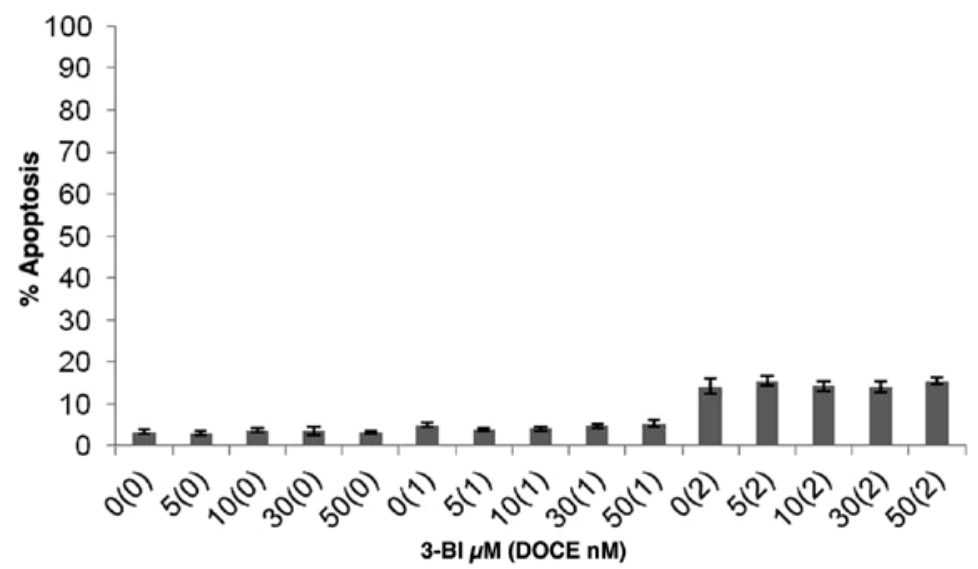

Figure 4. Quantitation of PC-3 apoptotic cells following $72 \mathrm{~h}$ of treatment with 3-BI and/or DOCE. No significant differences were found compared with the control treatment. 3-BI, 3-butenyl isothiocyanate; DOCE, docetaxel.

proteins could acquire oncogenic properties that are different to those resulting from loss of wild-type tumor-suppressing p53 function and that could promote proliferation, survival, migration, invasion and metastasis. STAT3 is an oncogenic 

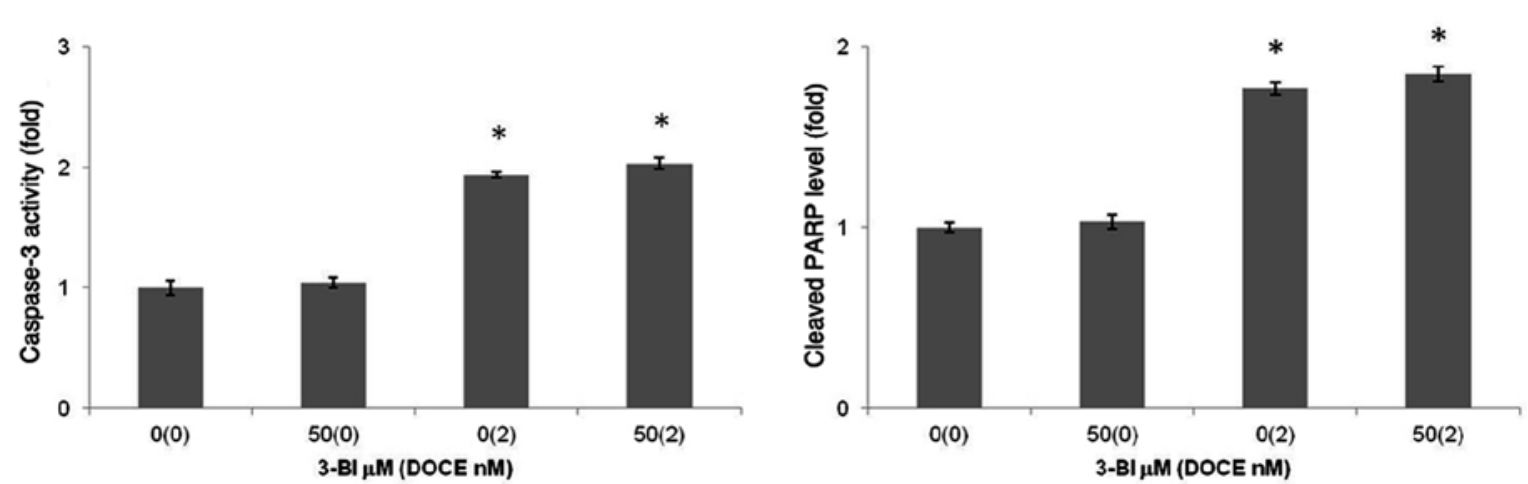

Figure 5. Active caspase-3 activity and cleaved PARP level in PC-3 cells following $72 \mathrm{~h}$ of treatment with dimethyl sulfoxide, 3-BI and/or DOCE. "P<0.05 compared with control treatment. 3-BI, 3-butenyl isothiocyanate; DOCE, docetaxel; PARP, poly(ADP-ribose) polymerase.

B

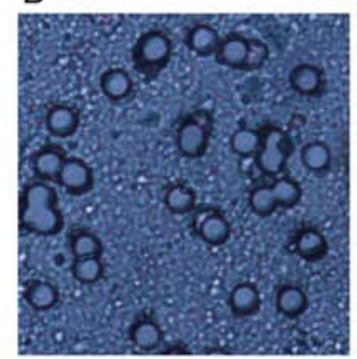

A

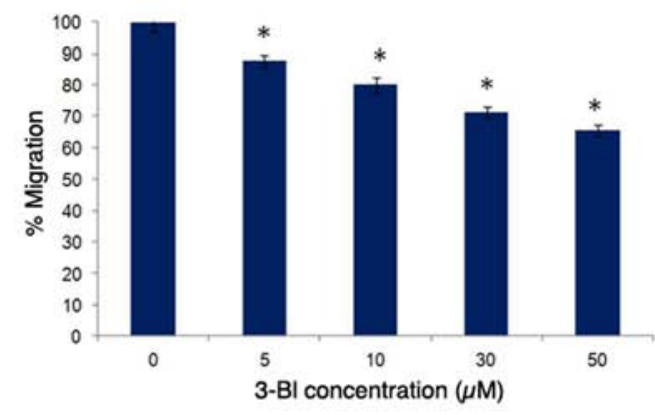

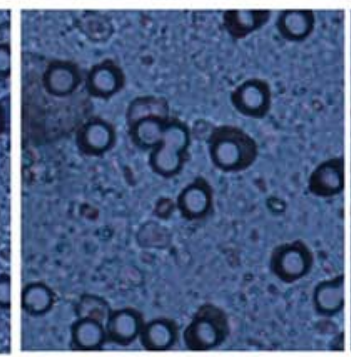

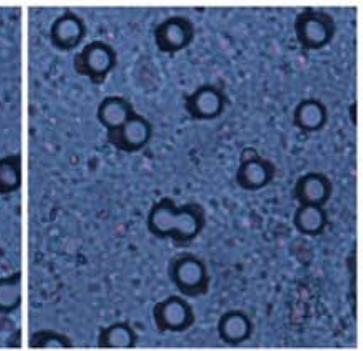

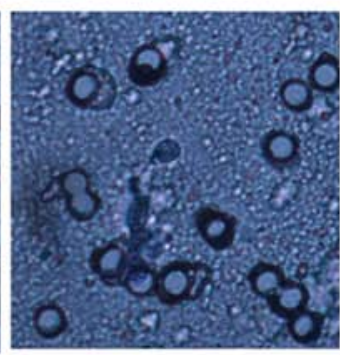

Figure 6. Effects of 3-BI on PC-3 cell migration. (A) 3-BI inhibited PC-3 cell migration. Experiments were repeated 3 times. "P<0.05 compared with control treatment. (B) Representative microphotographs of PC-3 cells (x40 magnification) that migrated through the chamber membranes following treatment with dimethyl sulfoxide (control) or 5, 10,30 and 50 $\mu \mathrm{M} 3$-BI (panels from left to right). 3-BI, 3-butenyl isothiocyanate.

transcription factor implicated not only in development, but also in PC progression, and is constitutively active in the DU145 cell line, but not in the PC-3 cell line. PTEN, a tumor suppressor gene, is mutated or lost in $50-80 \%$ of primary PC cases, with the complete loss associated with aggressiveness and metastasis. Likewise, Akt is constitutively active in the PC-3 cell line, but not in the DU145 cell line, due to the lack and the robust expression of PTEN, respectively (5). Nevertheless, the PTEN loss-induced Akt pathway promotes cell survival, proliferation and metastasis in DU145 and PC-3 cells (64).

With regard to the ability of $\mathrm{PC}$ to metastasize, the present study showed that the migration of PC-3 cells is reduced significantly by 3-BI treatment. Migration involves changes in the motility and adhesion of PC cells that are associated with metastasis (65). Inhibition of E-cadherin expression is considered as one of the main indicators of the epithelial/mesenchymal phenotype transition of PC, diminishing cell-cell adhesion and facilitating metastasis (66). Certain ITCs can modulate the expression of a variety of metastasis target genes. The regulation of migration is quite complex and is mediated by Bcl-2, p53, Akt, PTEN, E-cadherin and MMP, among others (33). Further studies are required to solve the differential 3-BI-induced response in PC-3 and DU145 cells. This could be of note, as anti-migratory drugs such as tyrosine kinase inhibitors are commonly used in CRPC $(14,15)$.

In addition, visualization of cytopathic changes by confocal microscopy could be a sensitive indicator for malignant progression and for the anti-invasive and cytotoxic drug effects. In particular, the reduction of cell size and the loss of cell appendages are considered as indicators of growth inhibitory and anti-invasive effects of anticancer compounds in PC-3 cells (67). In the present study, it was found that 3-BI with or without DOCE exhibits cytopathic effects in PC-3 cells, manifested by cell morphology changes and actin skeleton reorganization. Härmä et al (67) showed that cell migration can be more rapid in elongated bipolar PC-3 cells in comparison to that in rounded cells. The changes in cell morphology and motility could be driven by organization of the actin cytoskeleton, likely 


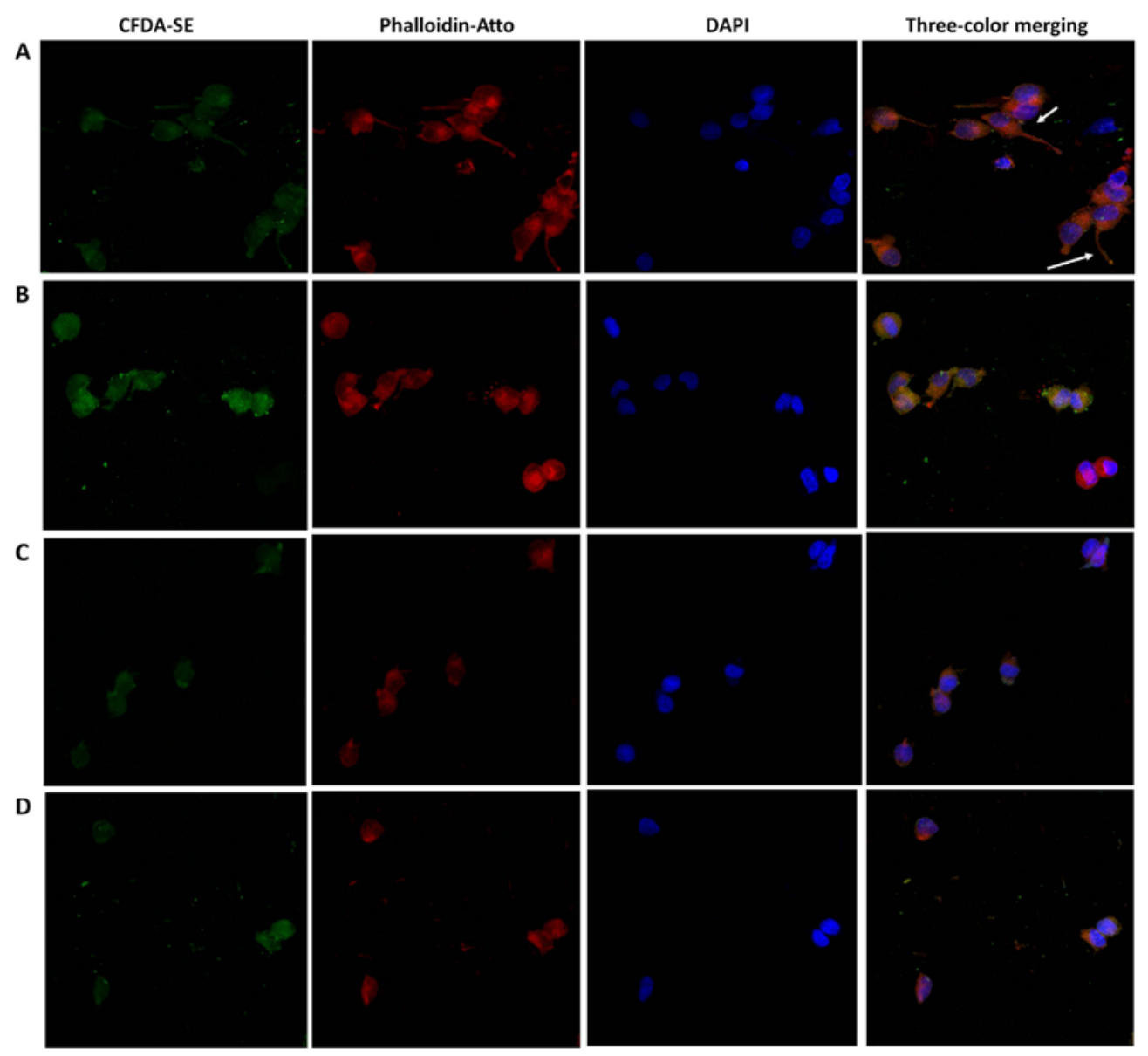

Figure 7. Scanning confocal microscopy of PC-3 cells. The images depict green (CFDA-SE), red (Phalloidin-Atto 647N) and blue (DAPI) stained cells, and a merger of the three channels. (A) Untreated PC-3 cells showed a more elongated phenotype with cytoplasmic projections (arrows) as compared with treated PC-3 cells. The cells treated with (B) 3-BI or co-treated with 3-BI and (C) $1 \mathrm{nM}$ or (D) $2 \mathrm{nM}$ showed predominantly a rounded shape phenotype with DNA condensation. DAPI, 4',6-diamidino-2-phenylindole; CFDA-SE, carboxyfluorescein diacetate succinimidyl ester; 3-BI, 3-butenyl isothiocyanate.

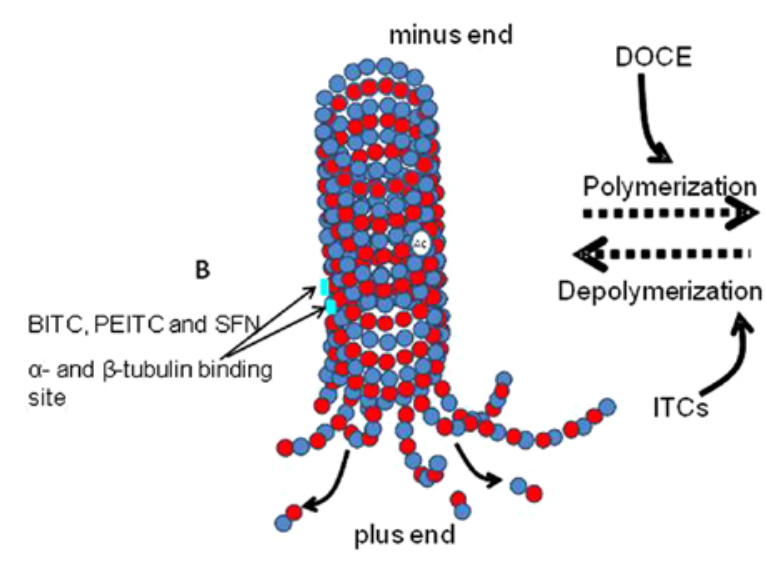

A DOCE $\beta$-tubulin binding site

\begin{tabular}{|ll}
\hline - $\beta$ tubulin subunit & AC acetylase \\
a tubulin subunit & tubulin heterodimer \\
HDAC III histone deacetylase
\end{tabular}

Figure 8. Possible mechanisms of 3-butenyl isothiocyanate microtubule-targeting effects. Tubulin-containing microtubules serve a pivotal role in different cellular processes, including cell division, motility and intracellular trafficking. Microtubules are dynamic polymers, formed by $\alpha$ and $\beta$ tubulin heterodimers, which undergo periods of polymerization and depolymerization. The dynamic process of polymerization and depolymerization is required to form mitotic spindles that are necessary to segregate the replicated chromosomes of the daughter cells. (A) DOCE binds to $\beta$-tubulin and stabilizes it. Subsequent to the union, the microtubules cannot be disassembled, so the static polymerization arrests the normal mitotic process in the G2M phase and finally induces cell death (49). (B) ITCs can bind to $\alpha$ and $\beta$ tubulin, inhibiting microtubule polymerization in vitro (human lung cancer A549 cells, human cervix cancer HeLa cells and mouse mammary carcinoma F3II cells) $(50,51,67)$, causing depolymerization $(51,67)$ or (C) inhibiting HDAC with increasing microtubule acetylation (51). The degree of binding affinity and microtubule polymerization inhibition is conditioned by the ITC structure $(51,52)$. DOCE, docetaxel; HDAC, histone deacetylase; ITC, isothiocyanate; BITC, benzyl ITC; PEITC, phenethyl ITC; SFN, sulphynilbutyl-ITC. 
mediated by putative motility modifiers $(68,69)$. A detailed study of these mechanisms requires further study and future research.

In conclusion, DOCE-based combination therapy was shown to increase the number and/or the duration of the therapeutic response in the present study. 3-BI demonstrated anti-proliferative and anti-migratory effects. Furthermore, 3-BI showed a synergic effect with DOCE without toxic effects on prostatic normal cells. According to these findings, 3-BI could be clinically attractive as an adjuvant to conventional chemotherapy with DOCE. The present results are promising, but further studies are required to determine the molecular mechanisms involved in 3-BI-induced cytotoxicity DOCE synergism.

\section{Acknowledgements}

This abstract was presented at the 7th Symposium on Brassica Crops, May 2017, in Pontevedra, Spain.

\section{Funding}

This study was supported by the Feder-Innterconecta project (ITC-20151009), the Spanish National Plan for Research and Development (grant no. AGL2015-66256-C2-1-R), and financed by the European Regional Development Funds.

\section{Availability of data and materials}

All data generated or analyzed during this study are included in this published article.

\section{Authors' contributions}

CG contributed substantially to the conception, design, drafting, critical revision and supervision of the submitted manuscript. PS contributed substantially to the analysis and interpretation of data, drafting, and technical and administrative support for the submitted manuscript. MEC and PV contributed substantially to the acquisition of data, drafting and administrative support for the submitted manuscript. SN, MJNI and MFG contributed substantially to the analysis and interpretation of data, design, drafting, critical revision and supervision of the submitted manuscript. All authors approved the final version to be published and agree to be accountable for all aspects of the work in ensuring that questions related to the accuracy or integrity of any part of the work are appropriately investigated and resolved.

\section{Ethics approval and consent to participate}

Not applicable.

\section{Patient consent for publication}

Not applicable.

\section{Competing interests}

Authors declare that they have no competing interests.

\section{References}

1. Zhou CK, Check DP, Lortet-Tieulent J, Laversanne M, Jemal A, Ferlay J, Bray F, Cook MB and Devesa SS: Prostate cancer incidence in 43 populations worldwide: An analysis of time trends overall and by age group. Int J Cancer 138: 1388-1400, 2016

2. Mitchell S, Abel P, Ware M, Stamp G and Lalani E: Phenotypic and genotypic characterization of commonly used human prostatic cell lines. BJU Int 85: 932-944, 2000.

3. Spiotto MT and Chung TD: STAT3 mediates IL-6-induced neuroendocrine differentiation in prostate cancer cells. Prostate 42: 186-195, 2000.

4. Mori K, Le Goff B, Charrier C, Battaglia S, Heymann D and Rédini F: DU145 human prostate cancer cells express functional receptor activator of NFkappaB: New insights in the prostate cancer bone metastasis process. Bone 40: 981-990, 2007.

5. van Duijn PW and Trapman J: PI3K/Akt signaling regulates p27(kip1) expression via Skp2 in PC3 and DU145 prostate cancer cells, but is not a major factor in p27(kip1) regulation in $\mathrm{LNCaP}$ and PC346 cells. Prostate 66: 749-760, 2006.

6. Proverbs-Singh T, Feldman JL, Morris MJ, Autio KA and Traina TA: Targeting the androgen receptor in prostate and breast cancer: Several new agents in development. Endocr Relat Cancer 22: R87-R106, 2015.

7. Quinn DI, Tangen CM, Hussain M, Lara PN Jr, Goldkorn A, Moinpour CM, Garzotto MG, Mack PCA, Carducci MA, Monk JP, et al: Docetaxel and atrasentan versus docetaxel and placebo for men with advanced castration-resistant prostate cancer (SWOG S0421): A randomised phase 3 trial. Lancet Oncol 14: 893-900, 2013.

8. Morin F, Beauregard JM, Bergeron M, Nguile Makao M, Lacombe L, Fradet V, Fradet Y and Pouliot F: Metabolic Imaging of Prostate Cancer Reveals Intrapatient Intermetastasis Response Heterogeneity to Systemic Therapy. Eur Urol Focus 3: 639-642, 2017.

9. Katzenwadel A and Wolf P: Androgen deprivation of prostate cancer: Leading to a therapeutic dead end. Cancer Lett 367: 12-17, 2015.

10. Gravis G, Fizazi K, Joly F, Oudard S, Priou F, Esterni B, Latorzeff I, Delva R, Krakowski I, Laguerre B, et al: Androgendeprivation therapy alone or with docetaxel in non-castrate metastatic prostate cancer (GETUG-AFU 15): A randomised, open-label, phase 3 trial. Lancet Oncol 14: 149-158, 2013.

11. Gillessen S, Omlin A, Attard G, de Bono JS, Efstathiou E, Fizazi K, Halabi S, Nelson PS, Sartor O, Smith MR, et al: Management of patients with advanced prostate cancer: Recommendations of the St Gallen Advanced Prostate Cancer Consensus Conference (APCCC) 2015. Ann Oncol 26: 1589-1604, 2015.

12. Ohlmann CH, Goebell PJ, Grimm MO, Klier J, König F, Machtens S, Schostak M, Schrader AJ and Albers P: Metastatic prostate cancer: Update: position paper for the use of chemotherapy. Urologe A 56: 1597-1602, 2017 (In German).

13. Oudard S, Fizazi K, Sengeløv L, Daugaard G, Saad F, Hansen S, Hjälm-Eriksson M, Jassem J, Thiery-Vuillemin A, Caffo O, et al: Cabazitaxel versus docetaxel as first-line therapy for patients with metastatic castration-resistant prostate cancer: A randomized phase III trial-FIRSTANA. J Clin Oncol 35: 3189-3197, 2017

14. Galsky MD and Vogelzang NJ: Docetaxel-based combination therapy for castration-resistant prostate cancer. Ann Oncol 21: 2135-2144, 2010

15. Pitcher B, Khoja L, Hamilton RJ, Abdallah K, Pintilie M and Joshua AM: Assessment of a prognostic model, PSA metrics and toxicities in metastatic castrate resistant prostate cancer using data from Project Data Sphere (PDS). PLoS One 12: e0170544, 2017.

16. Hwang C: Overcoming docetaxel resistance in prostate cancer: A perspective review. Ther Adv Med Oncol 4: 329-340, 2012

17. Attard G, Parker C, Eeles RA, Schröder F, Tomlins SA, Tannock I, Drake CG and de Bono JS: Prostate cancer. Lancet 387: 70-82, 2016

18. Mouhid L, Corzo-Martínez M, Torres C, Vázquez L, Reglero G, Fornari T and Ramírez de Molina A: Improving in vivo efficacy of bioactive molecules: An overview of potentially antitumor phytochemicals and currently available lipid-based delivery systems. J Oncol 2017: 7351976, 2017.

19. Tummala R, Lou W, Gao AC and Nadiminty N: Quercetin targets hnRNPA1 to overcome enzalutamide resistance in prostate cancer cells. Mol Cancer Ther 16: 2770-2779, 2017.

20. Zhang Y and Talalay P: Anticarcinogenic activities of organic isothiocyanates: Chemistry and mechanisms. Cancer Res 54 (Suppl 7): 1976s-1981s, 1994. 
21. Zhao B, Seow A, Lee EJ, Poh WT, Teh M, Eng P, Wang YT, Tan WC, Yu MC and Lee HP: Dietary isothiocyanates, glutathione S-transferase -M1, -T1 polymorphisms and lung cancer risk among Chinese women in Singapore. Cancer Epidemiol Biomarkers Prev 10: 1063-1067, 2001.

22. Ambrosone CB, McCann SE, Freudenheim JL, Marshall JR Zhang Y and Shields PG: Breast cancer risk in premenopausal women is inversely associated with consumption of broccoli, a source of isothiocyanates, but is not modified by GST genotype. J Nutr 134: 1134-1138, 2004.

23. Halkier BA and Gershenzon J: Biology and biochemistry of glucosinolates. Annu Rev Plant Biol 57: 303-333, 2006.

24. Guo Z, Smith TJ, Wang E, Eklind KI, Chung FL and Yang CS: Structure-activity relationships of arylalkyl isothiocyanates for the inhibition of 4-(methylnitrosamino)-1-(3-pyridyl)-1-butanone metabolism and the modulation of xenobiotic-metabolizing enzymes in rats and mice. Carcinogenesis 14: 1167-1173, 1993.

25. Rampal G, Thind TS, Arora R, Vig AP and Arora S: Synergistic antimutagenic effect of isothiocyanates against varied mutagens. Food Chem Toxicol 109: 879-887, 2017

26. Papi A, Orlandi M, Bartolini G, Barillari J, Iori R, Paolini M, Ferroni F, Grazia Fumo M, Pedulli GF and Valgimigli L: Cytotoxic and antioxidant activity of 4-methylthio-3-butenyl isothiocyanate from Raphanus sativus L. (Kaiware Daikon) sprouts. J Agric Food Chem 56: 875-883, 2008.

27. Cheung KL and Kong AN: Molecular targets of dietary phenethyl isothiocyanate and sulforaphane for cancer chemoprevention. AAPS J 12: 87-97, 2010.

28. Wu CL, Huang AC, Yang JS, Liao CL, Lu HF, Chou ST, Ma CY, Hsia TC, Ko YC and Chung JG: Benzyl isothiocyanate (BITC) and phenethyl isothiocyanate (PEITC)-mediated generation of reactive oxygen species causes cell cycle arrest and induces apoptosis via activation of caspase-3, mitochondria dysfunction and nitric oxide (NO) in human osteogenic sarcoma U-2 OS cells. J Orthop Res 29: 1199-1209, 2011

29. Kadir NH, David R, Rossiter JT and Gooderham NJ: The selective cytotoxicity of the alkenyl glucosinolate hydrolysis products and their presence in Brassica vegetables. Toxicology 334: 59-71, 2015.

30. Arora R, Kumar R, Mahajan J, Vig AP, Singh B, Singh B and Arora S: 3-Butenyl isothiocyanate: A hydrolytic product of glucosinolate as a potential cytotox ic agent against human cancer cell lines. J Food Sci Technol 53: 3437-3445, 2016.

31. Okamura T, Umemura T, Inoue T, Tasaki M, Ishii Y, Nakamura Y, Park EY, Sato K, Matsuo T, Okamoto S, et al: Chemopreventive effects of 4-methylthio-3-butenyl Isothiocyanate (Raphasatin) but not curcumin against pancreatic carcinogenesis in hamsters J Agric Food Chem 61: 2103-2108, 2013.

32. Suzuki I, Cho YM, Hirata T, Toyoda T, Akagi JI, Nakamura Y, Sasaki A, Nakamura T, Okamoto S, Shirota K, et al: Toxic effects of 4-methylthio-3-butenyl isothiocyanate (Raphasatin) in the rat urinary bladder without genotoxicity. J Appl Toxicol 37: 485-494, 2017.

33. Novío S, Cartea ME, Soengas P, Freire-Garabal M and Núñez-Iglesias MJ: Effects of Brassicaceae isothiocyanates on prostate cancer. Molecules 21: E626, 2016.

34. Padilla G, Cartea ME, Velasco P, de Haro A and Ordás A: Variation of glucosinolates in vegetable crops of Brassica rapa. Phytochemistry 68: 536-545, 2007.

35. Smith TK, Lund EK, Clarke RG, Bennett RN and Johnson IT: Effects of Brussels sprout juice on the cell cycle and adhesion of human colorectal carcinoma cells (HT29) in vitro. J Agric Food Chem 53: 3895-3901, 2005.

36. Xiao D, Choi S, Johnson DE, Vogel VG, Johnson CS, Trump DL, Lee YJ and Singh SV: Diallyl trisulfide-induced apoptosis in human prostate cancer cells involves c-Jun N-terminal kinase and extracellular-signal regulated kinase-mediated phosphorylation of Bcl-2. Oncogene 23: 5594-5606, 2004.

37. Xiao D, Vogel V and Singh SV: Benzyl isothiocyanate-induced apoptosis in human breast cancer cells is initiated by reactive oxygen species and regulated by Bax and Bak. Mol Cancer Ther 5: 2931-2945, 2006.

38. Mao L, Yang C, Wang J, Li W, Wen R, Chen J and Zheng J: SATB1 is overexpressed in metastatic prostate cancer and promotes prostate cancer cell growth and invasion. J Transl Med 11: 111, 2013.

39. da Silva Ferreira R, Zhou D, Gasperazzo J, Cabral MC, Silva-Lucca RA, Mentele R, Paredes-Gamero EJ, Bertolin TC, dos Santos MT, Guedes PM et al: Crystal structure of Crataeva tapia bark protein (CrataBL) and its effect in human prostate cancer cell lines. PLoS One 8: e64426, 2013.
40. Lee HY, Oh SH, Suh YA, Baek JH, Papadimitrakopoulou V, Huang S and Hong WK: Response of non-small cell lung cancer cells to the inhibitors of phosphatidylinositol 3-kinase/ Akt- and MAPK kinase 4/c-Jun NH2-terminal kinase pathways: An effective therapeutic strategy for lung cancer. Clin Cancer Res 11: 6065-6074,2005.

41. Fimognari C, Nüsse M, Iori R, Cantelli-Forti G and Hrelia P: The new isothiocyanate 4-(methylthio)butylisothiocyanate selectively affects cell-cycle progression and apoptosis induction of human leukemia cells. Invest New Drugs 22: 119-129, 2004.

42. Barillari J, Iori R, Papi A, Orlandi M, Bartolini G, Gabbanini S, Pedulli GF and Valgimigli L: Kaiware Daikon (Raphanus sativus L.) extract: A naturally multipotent chemopreventive agent. J Agric Food Chem 56: 7823-7830, 2008.

43. Papi A, Farabegoli F, Iori R, Orlandi M, De Nicola GR, Bagatta M, Angelino D, Gennari L and Ninfali P: Vitexin-2-O-xyloside, raphasatin and (-)-epigallocatechin-3-gallate synergistically affect cell growth and apoptosis of colon cancer cells. Food Chem 138: 1521-1530, 2013.

44. Zhang Y, Yao S and Li J: Vegetable-derived isothiocyanates: Antiproliferative activity and mechanism of action. Proc Nutr Soc 65: 68-75, 2006.

45. Zhang Y: The molecular basis that unifies the metabolism, cellular uptake and chemopreventive activities of dietary isothiocyanates. Carcinogenesis 33: 2-9, 2012.

46. Wang N, Wang W, Huo P, Liu CQ, Jin JC and Shen LQ: Mitochondria-mediated apoptosis in human lung cancer A549 cells by 4-methylsulfinyl-3-butenyl isothiocyanate from radish seeds. Asian Pac J Cancer Prev 15: 2133-2139, 2014.

47. Daja MM, Niu X, Zhao Z, Brown JM and Russell PJ: Characterization of expression of matrix metalloproteinases and tissue inhibitors of metalloproteinases in prostate cancer cell lines. Prostate Cancer Prostatic Dis 6: 15-26, 2003.

48. Tai S, Sun Y, Squires JM, Zhang H, Oh WK, Liang CZ and Huang J: PC3 is a cell line characteristic of prostatic small cell carcinoma. Prostate 71: 1668-1679, 2011.

49. Stanton RA, Gernert KM, Nettles JH and Aneja R: Drugs that target dynamic microtubules: A new molecular perspective. Med Res Rev 31: 443-481, 2011.

50. Mi L, Xiao Z, Hood BL, Dakshanamurthy S, Wang X, Govind S, Conrads TP, Veenstra TD and Chung FL: Covalent binding to tubulin by isothiocyanates. A mechanism of cell growth arrest and apoptosis. J Biol Chem 283: 22136-22146, 2008.

51. Mi L, Gan N, Cheema A, Dakshanamurthy S, Wang X, Yang DC and Chung FL: Cancer preventive isothiocyanates induce selective degradation of cellular alpha- and beta-tubulins by proteasomes. J Biol Chem 284: 17039-17051, 2009.

52. Xiao Z, Mi L, Chung FL and Veenstra TD: Proteomic analysis of covalent modifications of tubulins by isothiocyanates. J Nutr 142: 1377S-1381S, 2012.

53. Magadoux L, Isambert N, Plenchette S, Jeannin JF and Laurens V: Emerging targets to monitor and overcome docetaxel resistance in castration resistant prostate cancer (review). Int J Oncol 45: 919-928, 2014. (review).

54. Zhu ML, Horbinski CM, Garzotto M, Qian DZ, Beer TM and Kyprianou N: Tubulin-targeting chemotherapy impairs androgen receptor activity in prostate cancer. Cancer Res 70: 7992-8002, 2010.

55. Khurana N, Talwar S, Chandra PK, Sharma P, Abdel-Mageed AB, Mondal D and Sikka SC: Sulforaphane increases the efficacy of anti-androgens by rapidly decreasing androgen receptor levels in prostate cancer cells. Int J Oncol 49: 1609-1619, 2016.

56. Kim SH and Singh SV: D,L-Sulforaphane causes transcriptional repression of androgen receptor in human prostate cancer cells. Mol Cancer Ther 8: 1946-1954, 2009.

57. Lane DP: Cancer. p53, guardian of the genome. Nature 358: $15-16,1992$.

58. Zhou M, Gu L, Li F, Zhu Y, Woods WG and Findley HW: DNA damage induces a novel p53-survivin signaling pathway regulating cell cycle and apoptosis in acute lymphoblastic leukemia cells. J Pharmacol Exp Ther 303: 124-131, 2002.

59. Qian J, Hirasawa K, Bostwick DG, Bergstralh EJ, Slezak JM, Anderl KL, Borell TJ, Lieber MM and Jenkins RB: Loss of p53 and c-myc overrepresentation in stage $\mathrm{T}(2-3) \mathrm{N}(1-3) \mathrm{M}(0)$ prostate cancer are potential markers for cancer progression. Mod Pathol 15: 35-44, 2002.

60. Strano S, Dell'Orso S, Di Agostino S, Fontemaggi G, Sacchi A and Blandino G: Mutant p53: An oncogenic transcription factor. Oncogene 26: 2212-2219,2007. 
61. Gan L, Wang J, Xu H and Yang X: Resistance to docetaxel-induced apoptosis in prostate cancer cells by p38/p53/p21 signaling. Prostate 71: 1158-1166, 2011.

62. Liu C,Zhu Y,Lou W, Nadiminty N, Chen X,Zhou Q, Shi XB, deVere White RW and Gao AC: Functional p53 determines docetaxel sensitivity in prostate cancer cells. Prostate 73: 418-427, 2013.

63. Muller PA and Vousden KH: p53 mutations in cancer. Nat Cell Biol 15: 2-8, 2013

64. Conley-LaComb MK, Saliganan A, Kandagatla P, Chen YQ, Cher ML and Chinni SR: PTEN loss mediated Akt activation promotes prostate tumor growth and metastasis via CXCL12/ CXCR4 signaling. Mol Cancer 12: 85, 2013.

65. Guan X: Cancer metastases: Challenges and opportunities. Acta Pharm Sin B 5: 402-418, 2015.

66. Wells A, Yates C and Shepard CR: E-cadherin as an indicator of mesenchymal to epithelial reverting transitions during the metastatic seeding of disseminated carcinomas. Clin Exp Metastasis 25: 621-628, 2008
67. Härmä V, Haavikko R, Virtanen J, Ahonen I, Schukov HP, Alakurtti S, Purev E, Rischer H, Yli-Kauhaluoma J, Moreira VM, et al: Optimization of Invasion-Specific Effects of Betulin Derivatives on Prostate Cancer Cells through Lead Development. PLoS One 10: e0126111, 2015.

68. Bai SW, Herrera-Abreu MT, Rohn JL, Racine V, Tajadura V, Suryavanshi N, Bechtel S, Wiemann S, Baum B and Ridley AJ: Identification and characterization of a set of conserved and new regulators of cytoskeletal organization, cell morphology and migration. BMC Biol 9: 54, 2011.

69. Jackson SJ and Singletary KW: Sulforaphane: A naturally occurring mammary carcinoma mitotic inhibitor, which disrupts tubulin polymerization. Carcinogenesis 25: 219-227, 2004. 